\title{
4 Cohesion Policy or Politics? A Case on the Participation of Civil Society
}

\author{
Oto Potluka ${ }^{20}$
}

\subsection{Introduction}

Partnership principle and participation help increase relevancy of policies. It also concerns the EU cohesion policy - one of the largest EU investment policies. Our study concentrates on the role of non-profit organisations in partnership and their added value in the Czech Republic, a country with very low perception concerning nonprofit organisations in policy-making among population. Based on 48 interviews with stakeholders from both the non-profit and the public sectors, who took active part in designing EU cohesion policy programmes, we draw our findings on capacities, relevance, and barriers of an effective participation of non-profit organisations in partnership processes in the Czech Republic.

Designing and implementing programmes, financed by the European Union (EU) cohesion policy, enhances partnership among sectors. Partners vary between firms, associations, non-profit organizations (NPOs), and public sectors at all levels. Though such partnership diversity brings different views on policy, it also helps achieve longterm sustainability and relevance of policies overall (OECD, 2001b: 18) ${ }^{21}$. Partnerships also involve EU cohesion policy objectives, especially as it relates to the dichotomy between social and economic development (Kalman, 2020). The European Union provides a legal framework for partnership implementation. The EU Regulation No. 1303/2013, Article 5, states that NPOs must take part in designing and implementing the EU cohesion policy as social partners. This policy covers the main fields of activity that NPOs are engaged in. Thus, it can be expected that NPOs will take an active role in this policy.

Involving partners with relevant knowledge and skills enables policy-makers to respond to peoples' needs. To identify these needs, relevant partners could be invited to provide the policy-makers and programme managers such knowledge. This can increase the relevance of selected solutions according to perceived societal needs. Moreover, in the case of the EU cohesion policy, satisfaction in needs that have been met could cause positive perceptions on territorial identity (Capello, 2018)-or EU identity and EU integration process. The current situation does not seem to reflect this

20 CEPS, University of Basel. Correspondence : oto.potluka@unibas.ch

21 See the cases of health policy, social policy, educational policy, or environmental policy in OECD (2001a).

Ә Open Access. (c) 2020 Ida Musiałkowska, Piotr Idczak, Oto Potluka and chapters' contributors. Published by De Gruyter. (c) BY-NC-ND This work is licensed under the Creative Commons Attribution-NonCommercial-NoDerivs 3.0 License. https://doi.org/10.1515/9788395720451-005 
as the EU territorial identity has not been clearly created (Capello, 2018). This raises several questions: Do the NPOs efficiently add to the cohesion policy design and implementation when they take part? What is the added value of NPOs in cohesion policy? Would intense participation in NPOs increase positive perception of the EU cohesion policy and the EU? Does it increase the relevance of the policy? Beyond these questions, the present paper investigates the following two key questions: What lessons can be drawn from the successes and failures of cohesion policy through involving NPOs in the design and implementation of this policy? What determines success and failure of programming when NPOs take part in it?

The added value this chapter contributes to the partnership theme is that the Czech Republic belongs to the countries with very low public sector support provisioned to other stakeholders when they take part in the design and implementation of public policies. Moreover, the Czech society tackles similar post-communist problems as other EU member states from Central and Eastern Europe, even though it has been almost three decades since the totalitarian regime collapsed. This study also concerns the perception of the population in these countries relating to the EU and integration processes. Thus, the Czech experience can reveal relevant solutions for the implementation of the EU cohesion policy in other EU member states.

The chapter is structured into five sections as follows: following the introduction, the next section outlines the partnership principle from the perspective of participation of NPOs in political decision-making and its relevance for the EU cohesion policy with respect to Czech NPOs. Section three is devoted to methodological issues, including data collection. Section four presents the results and discussion in seven parts according to the characteristics of the ideal partnership process. Finally, section five presents the conclusion drawn from the data analysis of our findings.

\subsection{Partnership Principle}

\subsubsection{NPOs in Political Decision-making}

The current disengagement of the electorate from participating in the political process between elections accentuates the significance of integrating the social partners including NPOs into the policy-creation process. While $12 \%$ of EU citizens perceive joining a political party as a means to influence public policies, $6 \%$ of them see the membership, or the support of an NPO, as a means to influence the political decision-making process (TNS Opinion \& Social, 2012: 44). The main difference is that the sole purpose of the political parties' existence is the facilitation of popular participation in politics and policy-making, while NPOs occupy completely different roles. Interestingly, according to $41 \%$ of European citizens, NPOs are not necessary (TNS Political \& Social, 2013: 9). 
Although Czechs view NPOs as being necessary (54\% pro; 40\% contra), their confidence in NPOs' capabilities to influence political decision-making is the lowest among all EU member states (TNS Opinion \& Social, 2012). The European perception of NPOs in politics differs. Among Europeans, 70\% of them see NPOs as capable of influencing political decision-making at a national level (TNS Political \& Social, 2013: 13). Only 55\% of Czech respondents hold this to be the case. Comparatively, on an EU-wide basis, the disparity is very similar with respectively $53 \%$ (EU) and 37\% (Czech Republic). Moreover, less than half of Czechs share values or interests with NPOs and trust their capabilities to be effective political agents to influence politics (TNS Political \& Social, 2013: 9).

Such circumstances are unique for a study of the main barriers that NPOs must tackle with when attempting to change policies. Moreover, the Czech Republic represents a case of a country belonging to the EU member states with the highest per capita allocations of EU cohesion policy funding. Thus, an analysis of the partnership principle implementation in such an environment can serve to highlight hidden barriers and help promote the effective implementation of this policy.

\subsubsection{Partnership Importance in EU Cohesion Policy}

The EU cohesion policy with a budget of EUR 351.8 bn. (EC, 2015) plays an important role in the EU investment policies, especially for development of regions lagging behind. Among the main objectives of the policy are the creation of jobs; an increase in competitiveness and economic growth at regional and company levels; sustainable development, and the improvement of quality of life standards (EC, 2015). These objectives make this policy interesting for many stakeholders, and are welcomed by the EC. Social partners, including civil society, European, national, regional and local-level partners should participate in the programming process, which includes design, implementation, monitoring and evaluation activities.

The partnership principle is not a recent issue for the EU cohesion policy. Previous programming periods, starting from 1994-1999, also encountered this in the past. For example, the partnership has been referred to in Article 4 of the Regulation 2081/1993. The member states implemented partnership "within the framework of each Member State's national rules and current practices" and "in full compliance with the respective institutional, legal and financial powers of each the partners." During that time, the European Union used the approach more extensively (Piattoni, 2009).

The scope of partnership principle implementation was more on consultancy level, but it had been further refined and broadened. Later, in the period between 2000-2006, a requirement on highest possible representativeness at all levels had been added to the Regulation 1260/1999 (the Article 8). Direct reference to civil society appeared in the Regulation 1083/2006, Article 11. Thus, the importance of civil society 
as partner for the EU cohesion policy grew in the programming period of 20072013. Moreover, the regulation required involvement of the partners in designing, implementing, and monitoring of all levels of policy-making (within the respective national strategic reference framework and all operational programmes).

The recent development goes further. Not only does Regulation 1303/2013 define partnership in a broader scope, but it also introduces a tool on how to implement it in Article 5. The European Code of Conduct on Partnership (EC, 2014) further provides elaborated guidelines on how to implement this principle. The partnership principle has undergone numerous developments ever since it has been introduced for the first time in the cohesion policy. Although the partnership is strongly rooted in the EU regulations, these regulations permit its implementation in accordance with national rules and practices. The size and role of civil society organizations also varies among Western European societies (Salamon \& Anheier, 1998; or Sissenich, 2010) depending on traditions and political culture. Constitutional arrangements influence the form of partnership in member states (Baun \& Marek, 2008: 33). This has a crucial consequence for partnership implementation in countries with low participative cultures or with a centralized public administration. It concerns mainly the Central and Eastern European countries (CEECs). In these countries, partnership is an informative process, rather than a consultation. As a result, a low level of involvement from NPOs on partnership is still prevalent in the EU cohesion policy (Kendall \& Anheier, 1999).

According to the social origins theory (Anheier, 2014; Salamon \& Anheier, 1998; Salamon, Sokolowski, \& Haddock, 2017), the CEECs have a statist non-profit sector model with less important civic engagement, volunteer input, and lower labour force working for civil society. Though the Czech Republic and Hungary have moved out of the statist group, they still do not have the same dominating patterns as other groups (Salamon et al., 2017). Taking into account the societal characteristics, our research results are applicable to countries with a similar non-profit sector model; especially those in the CEECs (Baun \& Marek, 2008: 11-12).

The ease of setting up a partnership is evident through the implementation of the acquis communitaire in accessing countries. Reasonably, the European Commission (EC) required implementing it, but within a short timeframe it had been implemented without accessing countries enabling partnership. These countries did not have the options to negotiate the scope and form of implemented policies (Grosse, 2010; Kutter \& Trappmann, 2010). Thus, the partnership processes and means were not ready for application in the shortened programming period 2004-2006 for that time accessing countries. One exception is the case of Eastern Germany, where the participative experience was introduced to the public administration from Western Germany in 1990 (Perron, 2014).

The implementation of the partnership principle developed throughout the two periods 2007-2013, and 2014-2020. All partners gained some experience (Potluka, Špaček, \& Remr, 2017). The progress in development is evident in the whole system 
and relates to capacities of both the managing authorities and beneficiaries. The approach to implementation of partnership, selected during the accession and postaccession period as political processes, results in a top-down approach to partnership implementation. Moreover, NPOs do not possess adequate financial and personnel capacities in the post-communist countries.

\subsubsection{Partnership \& Policy Relevance}

In democratic countries, political parties offer their programmes to attract the attention of voters. This means that, at least before elections, they are interested in voters' opinions ${ }^{22}$. What happens in the timeframe between elections? Are the public needs so irrelevant as to be unknown to politicians? For long-term relevance, acceptance and sustainability of public policies, knowledge of the public's needs is crucial (EC, 2004: 9; Kelleher, Batterbury, \& Stern, 1999: 16). Public participation is not only important because programmes have to help solve public problems, but also because of the co-financing the EU cohesion policy programmes from the national public budgets. Neglecting these needs may cause problems for programme ownership, which can lead to further issues, risking the programmes' outcomes. From this point of view, Mairate (2006) identified partnership as a condition influencing greater effectiveness in the EU cohesion policy.

On one side, even partnership may cause some problems. Milio (2014) and Perron (2014) pointed out that rent-seeking and democratic deficit are issues that also concern EU cohesion policy implementation. In such cases, it is necessary to be aware of the defining aspects of a partnership. They cover whether or not the partnership is successful as well as the following seven issues: First, clarity and sharing of the partnership's goals by all partners, where partners perceive the goals the same way and their attempt to achieve them. Second, partnership provides benefits to all partners, where partnership provides positive internal value to each partner. Third, long-term cooperation of partners, where partnership is not only limited to one shortterm project. Fourth, acceptance of the form of partnership, partners understand and accept the means of work. Fifth, added value of each partner, where each partner contributes added value and what would otherwise be missing. Sixth, positive external value of partnership, where synergy in the total effects of partnership is higher than the sum of separate effects of each partner. Seventh and finally, decisions are made by all partners, where decision is based on the consent of all partners.

The EU cohesion policy is specific in its programming cycle. The managing authorities collect needs about three or two years before the programming period

22 Consult the literature about political-business cycle in CEECs in Hallerberg, Vinhas de Souza, and Clark (2002). 
starts. The programming period is seven years long. Together with the rule, $\mathrm{N}+2$ (twoyear period to finalize the payments), it initiates 11 years of implementation. It is clear that it is a long time for the needs to remain unchanged.

\subsubsection{Development of Civil Societies' Capacities in CEECs: Focus on The Czech Republic}

Although partnership studies are mainly from a political point of view, the civil society development has two aspects: economic and political (Lane, 2010). Eastern and Western European countries witnessed different developments. The Western European countries developed economically first which allowed civil societies in these countries to take part in social and political life. Post-socialist countries were under a time pressure in the 1990s, thus trying to transform their societies simultaneously in both dimensions. As a result, the economic foundations of civil society in postcommunist countries are not sufficiently strong to provide political activism. As such, the political parties remain the core decision-makers in politics (Frič, 2004). Positions of former president, Vaclav Havel, and the Prime Minister, Vaclav Klaus, reflected such a clash of attitudes towards civil society in the Czech Republic (Potůček, 1999). While Havel was a proponent of civil society, Klaus supported the role of political parties as core brokers in political decision-making without participation of any other agents, especially civil society organisations.

In theory, the partnership principle allows NPOs to take part in political decisionmaking. From this perspective, the accession of the Czech Republic into the European Union in 2004 offered new opportunities to Czech NPOs, especially in the field of the EU cohesion policy ${ }^{23}$. There was quite a high awareness among Czech NPOs about partnership and requirements for participation in the political decision-making process, including EU cohesion policy (Černá \& Marek, 2003: 174-175). In contrast, NPOs suffered from insufficient capacities, either economic or socio-political (Frič, 2004; Rose-Ackerman, 2007).

Heterogeneity and missing support of umbrella associations had caused a need for the public sector to cooperate with heterogeneous groups of NPOs (Černá \& Marek, 2003). Together with low awareness on how to participate in partnership and capacities among NPOs, this resulted in the selection of NPOs' representatives for monitoring committees to be based on willingness of these people to take part. Thus, the selection process was criticized for its lack of transparency.

Soon after the accession, disillusionment among civil society organisations followed expectations in all new member states (Harvey, 2004). The crucial issue in

23 These expectations concerned all Central and Eastern European countries. For details, see Sudbery (2010). 
NPO capacities to take effective part in partnership is the lack of sufficient capacities. Most importantly are the financial capacities, which would enable NPOs to get personnel, equipment, and so on (Bowman, 2011; Carmin, 2010). Lack of funding has led NPOs to sacrifice planning long-term strategic objectives and, instead, focus on achieving short-term operational goals (Chin, 2017). It caused a shift from NPO objectives and issues to providing parts of public-policy programmes. The situation did not improve much in the second nor in the third programming period after accession (Polverari \& Michie, 2009; Potluka, Špaček, et al., 2017).

The lack of strategic approach from the civil society sector is also evident in its inability to set up self-governing bodies until the beginning of the 2000s. These would be representatives in negotiations with the public sector. Such roof associations would represent the civil society sector in partnership with the public sector. Too many individual stakeholders make the policy discussion difficult to manage. Thus, pre-negotiation within associations could settle these complications and sort out heterogeneous ideas.

Two types of associations appeared in the 2000s. First, national associations that unified civil society as a generic sector and creating self-administration in the sector. Such a case is the Association of NPOs in the Czech Republic (ANNO). Second, a group of associations represent interests on their field of specialisation. Some regional associations became members of the ANNO, making it difficult in turn, for public servants to ascertain representativeness of the $\mathrm{ANNO}^{24}$. Another deficiency of this umbrella organization is that it does not cover sport and environmental NPOs (Pospíšilová, 2014: 7). Moreover, a new association has been set up in 2010, The Association of Public Benefit Organizations in the Czech Republic.

\subsection{Data \& Methodology}

We base the current study on a combination of information derived from official documents, data collected via in-depth interviews, and focus-group methods. By applying this approach, we cover not only the providers of the opportunity to take part in designing public policy (managing authorities), but also on those that benefit from this opportunity (NPOs).

Two groups of interviewees took part in the data collection. Czech NPO managers and experts constitute the first group. To be invited in the interviews, they had to have experience from the monitoring committees during the programming period 2007-2013, or be members of working groups set up by NPOs for the programming period 2014-2020. Employees of the managing authorities compose the second group

24 For an overview of representation among associations see Potluka, Špaček, et al. (2017). 
(see below). Some of the interviewees had sufficient experience with the partnership and knowledge relating to the EU cohesion policy.

\subsubsection{First Group of Interviewees}

First, we collected a list of contacts of NPO representatives who were members of the Monitoring Committees (MCs) and working groups. The Czech Republic's Committee for the EU of the Government Council for Non-Governmental Non-profit Organisations and the ANNO provided us with the list of contacts. The websites of the particular operational programmes provided us with additional information and contacts.

We succeeded in collecting contact information for the 94 NPO representatives participating in the partnership for design and implementation of the EU funded programmes in the Czech Republic in the periods 2007-2013 and 2014-2020. Based on this, we succeeded in conducting 48 interviews with NPO representatives between July and September 2014. The associations' representatives were the main targets of our interviews, as they could provide information about other NPOs. Together with 15 national, and 10 regional, associations, six influential NPOs were represented in this sample. The other interviewees represented small NPOs (17), individuals who act as NPO position-makers, and experts from NPOs with an expertise in EU cohesion policy.

\subsubsection{The Second Group of Interviewees}

Representatives of managing authorities of regional and thematic operational programmes represent the second group of interviewees. From the 17 programmes implemented in the Czech Republic in the periods 2007-2013 and 2014-2020, we selected those who are the most interesting for the NPOs. Those are either programmes funded by the European Social Fund (ESF) or regional programmes. Among them, three interviewees were from the public sector representing programmes at regional level and five from national level. Moreover, interviews were conducted with two employees of the Committee for the EU of the Government Council for NonGovernmental Non-profit Organisations. These interviews were conducted between September and October 2014.

\subsubsection{Interviews}

During the interviews, we have discussed questions relating to ideal form of partnership and experience with it, participation of NPOs in the EU cohesion policy designing and implementation, and vision on how to implement this principle. We have defined questions according to the previous studies on partnership in the EU 
cohesion policy by Adshead (2014); Gazley (2010); Milio (2014); Potluka and Liddle (2014). If needed, further questions also concerned personal expectations of the partners and their fulfilment.

To triangulate findings from different methods, we used (i) official documentation, (ii) in-depth-interviews, (iii) a focus group (held in October 2014 with 12 participants), and (iv) two rounds of peer-reviews (October and November 2014). This approach allowed us to construct a problem tree (EC, 2004) with the cause-effect relationships in the process of implementation of the partnership (see the Figures 1-3).

\subsection{Results \& Discussion}

The analysis was conducted as though the partnership principle would be implemented in an ideal form, where partners benefit according to the core principles of the partnership principle (see the seven core aspects in the methodological section). It reveals what the main barriers to management of partnership principle in the Czech Republic are, but also that the capacities are developing on both the civil and public sectors levels. The particular results are discussed in the following subsection. The main issues, causes, and effects are visualised in the problem trees.

\subsubsection{Clarity And Acceptance Of Goals By All Partners}

Public sector has a clear goal in the EU cohesion policy: to prepare programming documentation and ensure that the programmes achieve a high absorption capacity. To achieve this goal, compliance with the demand-side of the programmes is needed. In the case of the public sector (municipalities, self-governing regions, and central public sector), the coordination mechanisms are given by the political system. For private companies and NPOs, it is given by partnership.

Variety of NPOs in their type, size, and activity-orientation belongs to their core characteristics (Pestoff, 2014). It also brings fragmentation of opinions and objectives. As so, it is quite difficult to make a consensus among NPOs. Participation of NPOs in particular working groups in which they are specialists solves such a situation. In specific fields, NPOs are capable of achieving consent as they are able to communicate similar issues. Another issue is the missing leaders among NPOs (contrary to political parties), who would be able to organise the sector and help set objectives. Hence, a lack of mutual communication about themes and common interests of civil society was missing. Likewise, the sharing of workload has transformed into a problem. Contrary to this statement, some interviewees declared positive practice in communication among NPOs; echoing a similar situation happening in the previous programming periods (Polverari \& Michie, 2009). 
Both the public administration and the civil society sectors perceive fragmentation among NPOs as an important barrier in implementation of the partnership principle. Three quarters of interviewees see particular interests as a problem of the civil society sector (Table 1). This situation is very similar to Hungary, Poland, and Romania for which Börzel and Buzogány (2010: 175-176) explain that, for environmental policies, there are missing stable relations among stakeholders.

Table 1: Particular interests as a barrier of partnership principle implementation.

\begin{tabular}{lllll}
\hline $\begin{array}{l}\text { Do you see particular interests of NPOs as a barrier of } \\
\text { partnership principle implementation } \\
\text { in the Czech Republic? }\end{array}$ & $\begin{array}{l}\text { Frequency } \\
\text { (N) }\end{array}$ & $\begin{array}{l}\text { All } \\
\text { Interviewees } \\
\text { (\%) }\end{array}$ & $\begin{array}{l}\text { Valid } \\
\text { responses } \\
\text { (\%) }\end{array}$ \\
\hline $\begin{array}{l}\text { Valid } \\
\text { responses }\end{array}$ & No & 9 & 18.8 & 24.3 \\
& Yes & 28 & 58.3 & 75.7 \\
& Total & 37 & 77.1 & 100.0 \\
$\begin{array}{l}\text { Missing } \\
\text { responses }\end{array}$ & Interviewee could not decide & 4 & 8.3 & \\
& No answer at all & 7 & 14.6 & \\
& Total & 11 & 22.9 & \\
& Total & 48 & 100.0 & \\
\hline
\end{tabular}

Source: In-depth interviews with NPOs' representatives.

Among NPOs active in designing EU cohesion policy programmes and project management, there are four groups cooperating closely only when they see their particular benefit from the cooperation. As Potluka, Špaček, et al. (2017) point out, these groups are usually gathered around a strong entity (an NPO or a network) both formal and informal, of which ANNO comes first. As an organisation disposing of a number of contacts among the top managers of other member associations (47, of which 17 other associations, mainly regional), it is capable of mobilizing other NPOs to actively participate. This is evident from the process of nominations of the NPOs representatives in the EU cohesion policy partnership. This mobilization is done through regional associations. The importance of this group is underlined by the Platform 2014+, organised by ANNO, together with other organisations. Seven out of ten elected candidates for the MCs, are members of the Partnership Platform 2014+. In contrast, this association is criticized by other NPOs because of its consistent lack of respect to other civil society groups when performing its activities. 
The second group has formed around an official public administration body, the Committee for the EU of the Government Council for Non-Governmental Non-profit Organisations. Being an advisory body of the Czech government, it has an advantage to communicate directly about EU issues between the Czech government and the civil society sector. Thus, other NPO representatives see it as a body representing the public sector interests and not of civil society.

The third group is a national network of local action groups. The local action groups engaged in their own way in the implementation of the EU cohesion policy in the programming period 2004-2006. They play the role of intermediary bodies, providing small-scale grants to micro-regional applicants. The decisions were made according to the partnership principle applied to the LEADER initiative, involving all key local stakeholders. Their position forms a partnership platform acting as an implementation structure. However, participation in the implementation process allowed the local action groups not only to gain experience, but also to be seen by their stakeholders as an element implementing the principle of partnership, achieving in turn, a respected position. The access to institutional funding, though not a large amount of money, makes the other groups of NPOs classify these groups as a part of the public sector.

The fourth group is the least structured, and consists of representatives of strong NPOs who bear their issues and promote them at any appropriate occasion. Preparation of new programming documents for the period 2014-2020 caused the NPOs to be able to unify across all platforms and groups and nominate representatives for all programmes. For a period of several months, they were able to create a great coalition in the Partnership Platform 2014+. Figure 1 (on the right side) shows the causes and effects of fragmentation among NPOs.

\subsubsection{Benefit for All Partners: Positive Internal Value}

Internal value gained from the partnership is an issue of relationship between activities and funding. If the NPOs have to provide their advocacy activities in the EU cohesion policy funded only by them, they have to find a counter-value to justify funding of its participation. This means that they must try to find information about future funding for their core activities from the new operational programmes, or the change in the system has to pay off their effort.

For the managing authorities, the internal value consists of formal and informal issues. This formal partnership enables them to fill the requirement of the European Commission on participation of social partners as stakeholders. The expertise, effort, and ideas provided by partners provides informal value added to the managing authorities. It varies according to partners involved, their experience, and effort. As Chin (2017) points out, policy advocacy in NPOs is the strongest at policy implementation 

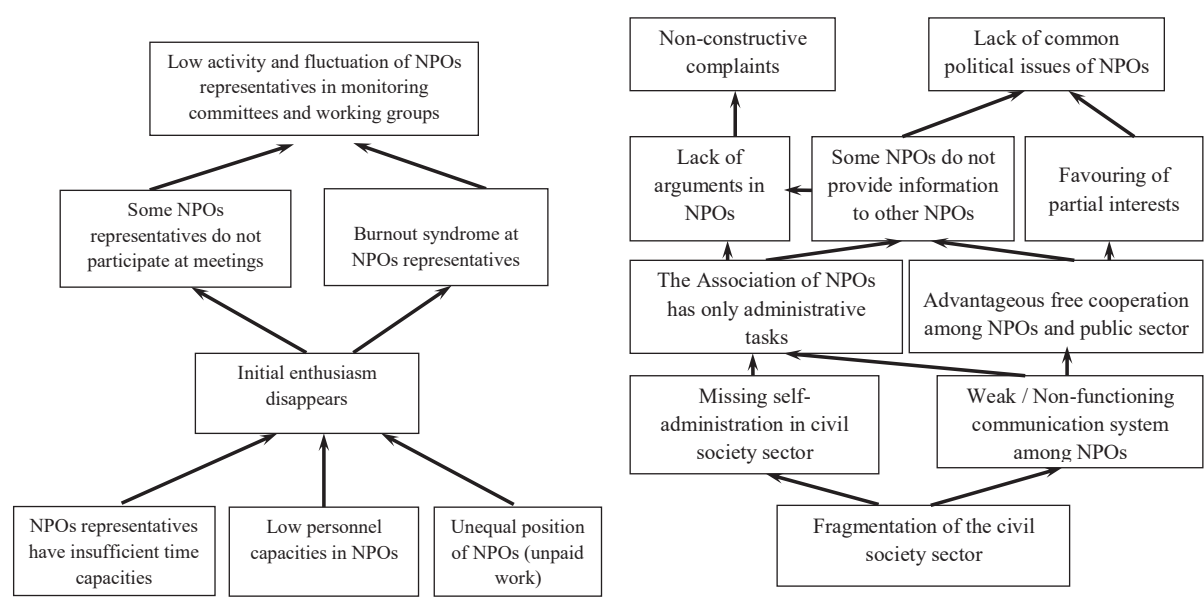

Figure 1. Causes and effects of problems in partnership of civil society and public sectors in the EU cohesion policy in the Czech Republic: Dependence on capacities and fragmentation of the civil society sector.

Source: in-depth interviews, own elaboration.

and administrative level within advisory and working groups in comparison to macropolicy level. Thus, the managing authorities could gain expertise and internal value according to the partners selected. It relates to the selection process in which the best appropriate partners are selected into the partnership.

Previous experience (programming periods 2004-2006, and 2007-2013) shows low knowledge of NPO sector within the public sector and lack of skilled experts to offer by the NPOs sector. Such a situation resulted in the selection of NPO representatives known to managing authorities without a selection process among NPO representatives. For the period 2014-2020, the selection process differed substantially. The NPOs selected their own candidates to represent them in Partnership Platform 2014+. This platform existed since 2012 and organized the nomination process within a few weeks in late 2012 and early 2013 to offer candidates of NPOs to all working groups in all operational programmes. This process was led by the ANNO. The initiative succeeded to collect 120 volunteering representatives from NPOs. Thus, 54 NPO representatives were actually selected, receiving the opportunity to participate in the partnership. This involvement proves high internal value for NPOs when they participate in designing the cohesion policy programmes.

As Potluka, Špaček, et al. (2017) found, representatives of both NPO and the public sector considered the system of pre-selection of NPO representatives by NPOs as efficient and transparent enough. It provides these representatives with a much stronger mandate and legitimacy in comparison to previous programming periods. NPOs were satisfied mainly with the bottom-up process, while the managing authorities with the representativeness of the participating NPOs. This process 
brought new experience as an unprecedented number of NPOs engaged in it. This variety entails the involvement of experienced NPO representatives, but also those who have no previous experience with the partnership principle and little knowledge of the EU funds management at all.

\subsubsection{Long-Term Cooperation Among Partners}

Reiterating from the section on internal value of partnership, the NPOs' highest effort concerned the creation of new priorities in the operational programmes. Partnership for following seven years enables partners to receive information directly on the focus of the operational programmes, if they fail to persuade managing authorities to accept their own proposals. As Potluka, Špaček, et al. (2017) point out, NPO initial interest declines gradually as they carry out their work in the working groups and MCs as volunteers. The authors mention that only two of all NPO representatives in the monitoring committees were willing to continue in their work for these bodies.

Moreover, the low ability of non-profit organizations to promote their intentions on the long-term causes disillusionment and diminished willingness to continue the partnership with the public administration. In combination with the fact that the costs (of work and transportation) of the NPO representatives are covered either by themselves or by their respective organizations, it is clear that this is not an interesting approach for the NPOs. Importance of funding to support the advocacy activities lead NPOs to convert their activities again to their previous day-to-day service provision to clients (Chin, 2017). According to the interviewees, about 26.7\% of NPO representatives lost their initial enthusiasm. This caused high fluctuation among the NPO representatives, as they did not a perceive long-term value for their participation.

Fluctuation does not concern only the NPO representatives, but also the management in the public sector. Here, the turnover is stronger due to change of government top managers after each election. From this perspective, long-term cooperation among partners seems to be a problematic issue. It is more or less formal as it lasts officially at macro-level, but at micro-level, changes appear and long-term memory disappears as people who left usually take their social know-how with them.

\subsubsection{Accepted Form of Cooperation}

The form of cooperation influences willingness of partners to cooperate. According to interviewees from NPOs, the form of partnership is impersonal. They were able to discuss some issues with the public sector, but it required more intense discussion. Even when proposing changes, it is not clear to many representatives of NPOs how the public sector addressed their comments. Comments with low importance (such as phrasing) were usually accepted. Some working groups have succeeded in persuading 
the Managing Authorities to expand the potential beneficiaries by NPOs. On the contrary, suggestions have been rejected on reallocation of support to NPO priorities.

NPOs entered the partnership process when the programming documents already existed. Representatives of new NPOs did not have much time to understand and to influence the focus of the upcoming programs. Working group meetings were often held in response to developments at national level or negotiations with the EC, without the possibility of producing strategic documents. This was partly due to the fragmented civil society sector. Already in 2011, representatives of the National Coordination Unit asked ANNO, which is considered to be a non-profit sector representative, to start the partnership process for NPOs. The ANNO did not share this information with other NPOs. The change in its attitude came with the change of the board of directors in ANNO. This has delayed the partnership process by several months.

Fragmentation of perception of the NPO representatives is evident as they see open communication with public sector. Opinions have emerged that have evaluated the positive attitude of the public sector as well as some criticisms of the form and content of the communication. Such a communication and participation resulted in a lacking long-term plan among NPOs on their participation. Figure $\mathbf{2}$ summarizes the causes and effects of the problematic attitude to the partnership process.

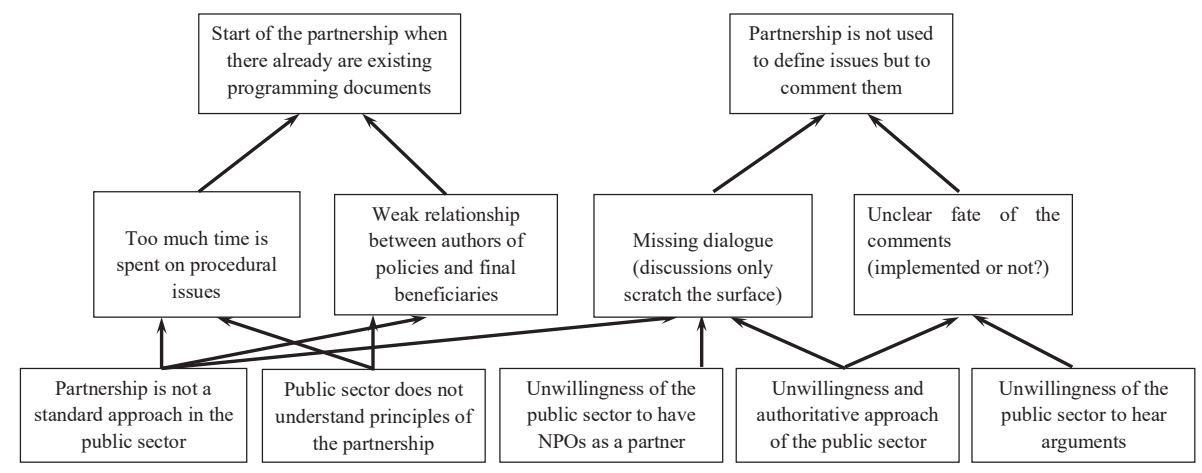

Figure 2: Causes and effects of problems in partnership of the civil society and public sectors in the EU cohesion policy in the Czech Republic: partnership process.

Source: in-depth interviews, own elaboration.

\subsubsection{Added Value of Each Partner: Adding to the Mosaic}

The majority of the implemented partnerships in the EU cohesion policy in the Czech Republic are still rather formal. There are three reasons for such a situation. First, the heritage of the statist system with a centralized political system (Salamon et al., 2017) lessens the role of the civil society in formulating public policies. Second, a 
need to meet the formal requirements of the EC and avoid any mistake in public administration results in a cautious approach to the public administration (opinion of $61.5 \%$ NPOs respondents). Third, even the member countries cannot fully apply partnership principle when negotiating with the European Commission. It concerns especially countries willing to access the EU (Grosse, 2010; Kutter \& Trappmann, 2010).

This general picture varies according to size and position of a body in the hierarchy of the implementation of the EU-funded operational programmes. Monitoring Committees are especially characteristic with their very formal procedures (Cartwright \& Batory, 2012), as they are large bodies meeting only a few times a year. The NPO representatives perceive the value added of each partner contentiously. The issue concerns their opinion about high skills and expertise among the NPO representatives who are not capable of persuading public administration in favour of their opinions. In contrast, they simultaneously appraise increasing openness of the public sector in the programming period 2014-2020.

Responses provide information that major issues appear in the partnership decision-making. Detailed analysis of responses shows that NPO representatives expected to influence the objectives of newly created operational programs, but the partnership process was more about commenting on documents than creating and prioritizing them. Still, they were able to provide the managing authorities with valuable information about local needs. The capacity to implement the partnership successfully depends on the personal approach of people from governing bodies and representatives of NPOs. To invite only relevant partners and avoid redundancy, the managing authorities invited only five NPO representatives to participate in working groups of each programme. Thus, all participating partners were able to provide missing information to the partnership process.

\subsubsection{Synergy of Partners: Positive External Value}

Fragmentation of the civil society sector results partially from lacking communication system among NPOs. Mutual communication among NPOs would not only raise awareness of the issues solved, but it would also increase the sharing of experiences and values within the whole sector. Such a system existed at the beginning of the Partnership Platform of NPOs 2014+ work with the aim to transform information about the process of operational programmes preparation and updates to NPOs. Each group had its coordinator responsible for sharing the information with the whole platform. It could help to increase absorption capacity of the operational programmes aimed at actual needs in society.

Such a system worked only in 2013, at the beginning of the existence of the Platform. Almost $60 \%$ of all interviewees pointed out that the discussion was not properly coordinated and NPOs were promoting their own interests without any 

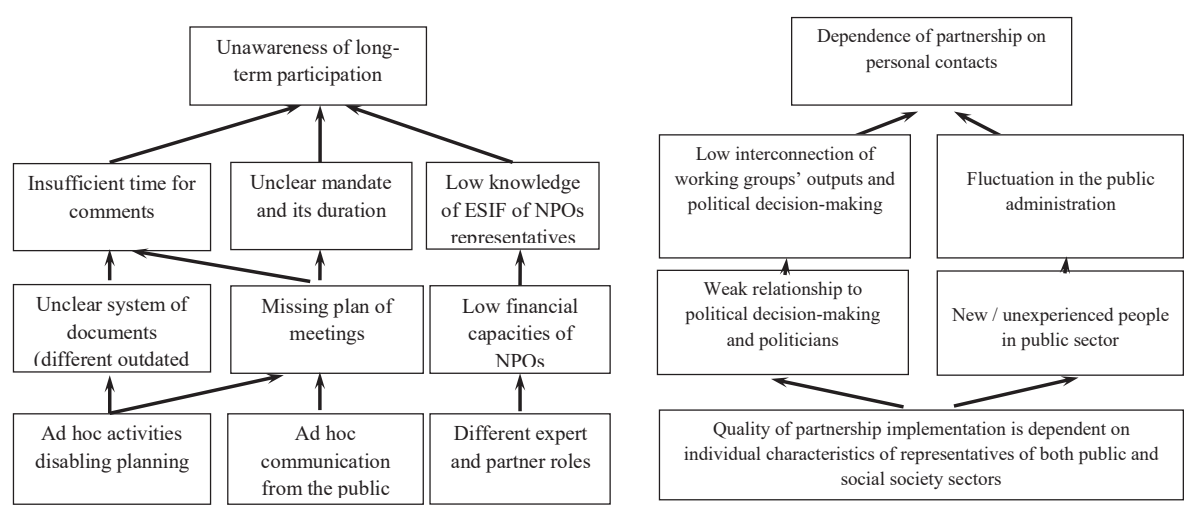

Figure 3: Causes and effects of problems in partnership of the civil society and public sectors in the EU cohesion policy in the Czech Republic: Unawareness and Fluctuation.

Source: in-depth interviews, own elaboration.

attempts to find consensus among NPOs. Sharing of information quickly disappeared when the amount of work and documents increased significantly. Some representatives of NPOs did not communicate even within the same working group. As a result, the participating NPOs were able to forward the information to a limited number of stakeholders only (Figure 3). Therefore, the positive external value of the partnership has decreased in this case, where it is uncertain whether or not it was missing entirely.

Another issue that reduces the external value of the partnership concerns timing. The beginning of the partnership principle with existing programming documents did not enable NPOs to interfere with the preparation of programming documents, but only when the first draft operational programs were prepared (Figure 3). Furthermore, due to procedural issues, the process was delayed and insufficient time was devoted to expert discussions and discussions with NPOs. In addition, only about half of NPO representatives were aware of the time-consuming process of seeking consensus among partners who have been involved in partner structures only in the recent programming period.

In addition to the lack of information on actual needs, delaying the timing of the intervention has caused barriers to the preparation of programming documents. Delays lead to insufficient time to comment on documents. This could be solved either by involving more employees or by lowering the output quality of the partnership process. Given that the overwhelming majority of NPOs have insufficient staffing capacity (Potluka, Špaček, et al., 2017; Potluka, Spacek, \& von Schnurbein, 2017) (reported by $75.0 \%$ of all NPO representatives), the only option was to reduce the quality of the inputs into partnership. Not only did the insufficient time capacities of NPOs cause a weak consultation process (58.3\% of respondents), the very short time to read and comment on documents was also perceived as the main problem. The special expertise of grass-root NPOs in the partnership is a general issue (Kohler- 
Koch, 2009), but the perceived lack of capacity among Czech NPOs is striking. Thus, the value created by participation could be higher if the NPOs had more capacities.

\subsubsection{Consensus Decisions}

Civil society is perceived to be among the necessary preconditions for democratization. They are brokers of ideas between the general public and public administration (Frič, Goulli, \& Vyskočilová, 2004; Kárníková, 2012; Quigley, 1996; Regulska, 1999). Relatively low level of political participation in the Central and Eastern European countries shows that one of the features of democratization in Eastern Europe is the low connection between civil society and citizens on one hand, and political parties on the other (Lewis, 2001). Enyedi and Linek (2008) mentioned that the reason for such a low membership in political parties in Central and Eastern European countries is the fact that parties are more oriented to an electoral logic. They mobilize their electorate and do not mobilize much of their internal sources.

Citizens cannot govern directly in contemporary large-scale societies (Strøm \& Müller, 2009: 25). According to Mair (1997: 97) the classic mass parties were a part of civil society as they grew from civil society and movements at the end of the $19^{\text {th }}$, and beginning of the $20^{\text {th }}$ centuries. The political parties' position has changed as the catch-all parties moved into a position between the civil society and the state.

Gallagher, Laver, and Mair (2006: 225) point out little stabilization of political parties in post-communist Europe. There continues to be a diminishing role of political parties however, in political decision-making in Central Europe as social movements gain influence (Maškarinec \& Klimovský, 2016; Šebík, 2016). Still, politicians are the decisive players in politics. Furthermore, almost half of interviewees see the resistance of the Czech public administration against the involvement of other partners in decision-making ${ }^{25}$. To sum up, although the political parties do not have sufficient internal capacities, they do not want to allow participation of other stakeholders in political decision-making.

Representatives of NPOs expected high openness in the partnership process when partnership is a requirement of the European Commission. About $50 \%$ of interviewees among NPO representatives perceive that there is no actual interest in the public sector to apply partnership principles. Moreover, more than $60 \%$ of them did not see the factual participation in decision-making.

Politics is predominant over policy in working group output implementation. Workgroup outputs are problem-oriented. It is therefore possible to find solutions to specific problems of the operational programmes proposed by the working groups'

25 For long-term reasons see Laboutkova (2009); Potuček (1999). 
experts. However, the transition of the output of the working groups into the political decision-making process reveals low actual implementation in real policy.

Another issue is a weak relationship between NPOs to political decision-making and politicians. NPO roles in the society are in agenda setting at the beginning of political decision-making, not in political decision-making as setting final decisionseven in a system which supports their active involvement as is the case for the EU cohesion policy (Kohler-Koch, 2009). Thus, the partnership principle also reflects this issue.

\subsection{Conclusion}

The practice of partnership process between NPOs and the public sector, as it is implemented in the Czech Republic, shows long-term improvement. Though there are improvements, there are still issues reducing its effects. We conclude that bigger participation of NPOs in policy design would not help increase popular perception of the EU cohesion policy and the EU among the population. There are two arguments for this. First, as the political parties and civil society are not connected any more (Mair, 1997), NPOs do not play an important role in political processes (Potluka, Špaček, et al., 2017). NPOs only have a chance to change policies in cases when they mobilize the masses for political action. In the whole post-communist region, NPOs are capable of developing a transactional capacity that seems to surpass the capacity to mobilize citizens in organized collective action (Petrova \& Tarrow, 2007). Second, ineffective communication channels among NPOs results in information not being provided to NPO target groups and the wider public. Thus, for the long-term change of the EU perception, narrowed communication channels are more beneficial than NPOs.

The NPOs are brokers of their target groups' needs, but they suffer from the lack of legitimacy to convince officials to take them seriously in policy-making processes. Thus, even though they have information on policy needs; their contribution to the policy relevance is limited. For the NPOs, it is thus better to stay outside the political process as a sector. If there were individual politicians being recruited as non-profit leaders, they would be able to lobby for the policy solutions suitable for NPOs-since there are still limited numbers of non-profit leaders willing to take an active part in politics and represent NPO values, even at local levels (Potluka \& Perez, 2019). Without such political engagement, NPOs would not be capable of improving relevance of implemented policies. In short, Table 2 summarizes the recent determinants, successes, and failures of Czech NPOs to implement the partnership process. 
Table 2: Summary of successes and failures of NPOs in the partnership process.

\begin{tabular}{|c|c|}
\hline Strengths & Weaknesses \\
\hline $\begin{array}{l}\text { - High effort of NPOs with regard to help } \\
\text { with to design the EU programmes } \\
\text { Knowledge of needs of specific target } \\
\text { groups }\end{array}$ & $\begin{array}{l}\text { - Low persuasive capacity of NPOs (lack of data } \\
\text { and rigorous analysis) } \\
\text { - } \quad \text { Fluctuation and loss of skilled people in NPOs } \\
\text { - } \quad \text { Fragmented civil society sector } \\
\text { NPOs coordination and communication among }\end{array}$ \\
\hline $\begin{array}{l}\text { Opportunities } \\
\text { - High willingness of NPOs to participate } \\
\text { in programming } \\
\text { - Transparent process of NPOs, } \\
\text { representatives selection } \\
\text { - Partnership process is more open than } \\
\text { in previous programming periods }\end{array}$ & $\begin{array}{l}\text { Threats } \\
\text { - Low NPOs' capacities (personnel, financial, } \\
\text { time) } \\
\text { - Low acceptance of partnership in public sector }\end{array}$ \\
\hline
\end{tabular}

Source: Own elaboration based on Potluka, Špaček, et al. (2017).

We have found a long-term positive development in the partnership principle, which satisfies both governing bodies and NPOs. Still, the implementation of partnership shows suboptimal interaction between the non-profit and public sector. The main obstacles to successful implementation of the partnership principle in the Czech Republic are the following four issues. The first and main problem relates to a huge fragmentation of the civil society sector in the Czech Republic. Fragmentation among NPOs is a natural process, thus it is not surprising that it prevents the creation of priorities and joint actions in this sector and requires more effort and time to achieve consensus. Uncoordinated activities sometimes reflect trends that concern the process, but do not add to improvement of public policies. If NPOs put in place coordination tools (such as a communication system or leaders capable of leading the process), they will achieve better results in the policy-making process.

The second important issue relates to the low capacities of NPOs in the partnership. The NPO representatives usually work at the expense of their own organisations. Sometimes, they work in their spare time and cover the financial costs of meetings from their own resources. Without successful results, such partners simply leave the partnership or stop being active. On the other hand, the partnership will acquire a formal, ineffective form that does not increase the importance of implemented policies. Supporting NPOs from cohesion policy (EC, 2014) would help them with low working and time capacities and could afford full-time experts to provide expertise for the sector as a whole (not to particular NPOs).

Thirdly, the fluctuation of civil society representatives hinders a functional partnership. However, fluctuations also concern public administration due to common changes in governing bodies for political reasons. Rotation in policy- 
making is the principle of democracy, but in this case, it also affects administrative staff. Fluctuations lead to the loss of previously established personal contacts, and partnerships not only become unsustainable, but requires reassembling. The problem is the lack of continuous long-term memory in working groups and the sharing of results among partners. This means that the situation does not meet the long-term relationship requirement. As noted above, capacity building would reduce the fluctuation of NPO representatives in MCs and working groups, and ultimately increase the ability of NPOs to operate.

The last question is the timing of the partnership. Late start and lack of time in partnership for prioritizing consultations lead to low quality outputs. It is in line with the three limitations of project management: cost, time and quality. It is simply not possible to achieve a high-quality partnership with a lack of time and financial resources in NPOs. From this perspective, it is up to the governing bodies to start a wider debate with reliable policy partners three years before the EC submission. Furthermore, improvement in the cooperation and a general rise in spirit among the NPOs themselves are of crucial importance. Creation of a working group of NPOs, which dealt with the issue of the EU cohesion policy, resulted in an increased activity and interest by NPOs in the Czech Republic. The ambitions of NPOs were one of the key factors that have led to a greater NPO representatives involvement in the preparation of programmes in the current programming period of 2014-2020.

What lessons can be drawn from the successes and failures of cohesion policy in involving NPOs in the design and implementation of this policy? Providing the opportunity to take part in the process without providing relevant sources does not help. NPOs were not able efficiently add to the cohesion policy design and implementation when they took part too late and with low capacities. The support of the European Commission in this process is essential and must be long-lasting; otherwise it will not continue in countries with centralized public administration. The support must be substantial, especially in relation to the current political development of the relationship of the central governments with civil society in the countries of Central Europe.

\section{References}

Adshead, M. (2014). EU cohesion policy and multi-level governance outcomes in Ireland: How sustainable is Europeanization? European Urban and Regional Studies, 21(4), 416-431. doi:10.1177/0969776413490426

Anheier, H. K. (2014). Nonprofit organisations: Theory, management, policy. Glasgow: Routledge.

Baun, M., \& Marek, D. (Eds.). (2008). EU cohesion policy after enlargement. New York: Palgrave Macmillan.

Börzel, T. A., \& Buzogány, A. (2010). Governing EU accession in transition countries: The role of nonstate actors. Acta Politica, 45(1-2), 158-182. doi:10.1057/ap.2009.26 
Bowman, W. (2011). Financial capacity and sustainability of ordinary nonprofits. Nonprofit Management and Leadership, 22(1), 37-51. doi:10.1002/nml.20039

Capello, R. (2018). Cohesion policies and the creation of a European identity: The role of territorial identity. JCMS: Journal of Common Market Studies, 56(3), 489-503. doi:10.1111/jcms.12611

Carmin, J. (2010). NGO capacity and environmental governance in Central and Eastern Europe. Acta Politica, 45(1-2), 183-202. doi:10.1057/ap.2009.21

Cartwright, A., \& Batory, A. (2012). Monitoring Committees in Cohesion Policy: Overseeing the Distribution of Structural Funds in Hungary and Slovakia. Journal of European Integration, 34(4), 323-340. doi:10.1080/07036337.2011.595486

Černá, M., \& Marek, J. (2003). NGOs and government in the Czech Republic in 2002. In J. Caddy \& C. Vergez (Eds.), Open Government: Fostering dialogue with civil society.

Chin, J. J. (2017). Service-providing nonprofits working in coalition to advocate for policy change. Nonprofit and Voluntary Sector Quarterly, 47(1), 27-48. doi:10.1177/0899764017721060

EC. (2004). Project cycle management guidelines. Brussels: EC.

EC. (2014). The European code of conduct on partnership in the framework of the European Structural and Investment Funds. Retrieved from Brussels:

EC. (2015). Total allocations of Cohesion Policy 2014-2020* (million €). Retrieved from http:// ec.europa.eu/regional_policy/en/funding/available-budget/

Enyedi, Z., \& Linek, L. (2008). Searching for the right organization: Ideology and party structure in East-Central Europe. Party Politics, 14(4), 455-477. doi:10.1177/1354068808090255

Frič, P. (2004). Politický vývoj ve střední Evropě po r. 1989 a jeho dopad na neziskový sektor. Retrieved from http://www.ceses.cuni.cz/CESES-20-version1-sesit04_03_fric.pdf

Frič, P., Goulli, R., \& Vyskočilová, O. (2004). Small development within the bureaucracy interests: The nonprofit sector in the Czech Republic. In A. Zimmer \& E. Priller (Eds.), Future of Civil Society: Making Central European Nonprofit-Organizations Work (pp. 601-634). Wiesbaden: VS Veralg für Sozialwissenschaften.

Gallagher, M., Laver, M., \& Mair, P. (2006). Representative government in modern Europe. Berkshire: McGraw-Hill.

Gazley, B. (2010). Linking collaborative capacity to performance measurement in governmentnonprofit partnerships. Nonprofit and Voluntary Sector Quarterly, 39(4), 653-673. doi:10.1177/0899764009360823

Grosse, T. G. (2010). Social dialogue during enlargement: The case of Poland and Estonia. Acta Politica, 45(1-2), 112-135. doi:10.1057/ap.2009.32

Hallerberg, M., Vinhas de Souza, L., \& Clark, W. R. (2002). Political business cycles in EU accession countries. European Union Politics, 3(2), 231-250.

Harvey, B. (2004). The illusion of inclusion: Access by NPOs to the structural funds in the new member states of eastern and central Europe. Retrieved from Brussels: http://www.ecascitizens.eu/index2.php?option=com_docman\&task=doc_view\&gid=742\&ltemid=99999999

Kalman, J. (2020). Effects of EU-Funds on Territorial Cohesion - Public and Private Resources for Regional Development in the Least-Developed, Most Deprived Micro-Regions in Hungary. In I. Musiałkowska, P. Idczak, \& O. Potluka (Eds.), Successes \& Failures in EU Cohesion Policy: An Introduction to EU cohesion policy in Eastern, Central, and Southern Europe (pp. 141-170). Warsaw/Berlin: De Gruyter. doi: 10.1515/9788395720451-008

Kárníková, A. (2012). Do they actually matter? The impact of NGOs on the European Instrument for Democracy and Human Rights (EIDHR). Perspectives: Central European Review Of International Affairs, 20(1), 83-109.

Kelleher, J., Batterbury, S., \& Stern, E. (1999). The thematic evaluation of the partnership principle: Final synthesis report. Retrieved from http://ec.europa.eu/regional_policy/sources/docgener/ evaluation/rathe_en.htm 
Kendall, J., \& Anheier, H. K. (1999). The third sector and the European Union policy process: an initial evaluation. Journal of European Public Policy, 6(2), 283-307. doi:10.1080/135017699343720

Kohler-Koch, B. (2009). The three worlds of European civil society-What role for civil society for what kind of Europe? Policy and Society, 28(1), 47-57. doi:10.1016/j.polsoc.2009.02.005

Kutter, A., \& Trappmann, V. (2010). Civil society in Central and Eastern Europe: The ambivalent legacy of accession. Acta Politica, 45(1-2), 41-69. doi:10.1057/ap.2009.18

Laboutkova, S. (2009). The establishment of NGOs as one growing part of developing interest groups in the Czech Republic. E+M Ekonomie a Management, 12(1), 14 -30.

Lewis, P. G. (2001). The `third wave’ of democracy in Eastern Europe: Comparative perspectives on party roles and political development. Party Politics, 7(5), 543-565. doi:10.1177/1354068801007005002

Mair, P. (1997). Party system change: Approaches and interpretations. Oxford: Clarendon Press.

Mairate, A. (2006). The 'added value' of European Union Cohesion policy. Regional Studies, 40(2), 167-177. doi:10.1080/00343400600600496

Maškarinec, P., \& Klimovský, D. (2016). Independent candidates in the local elections of 2014 in the Czech Republic and Slovakia: Analysis of determinants of their successfulness. Lex Localis Journal of Local Self-Governmnet, 14(4), 853-871. doi:10.4335/14.4.853-871(2016

Milio, S. (2014). The conflicting effects of multi-level governance and the partnership principle:Evidence from the Italian experience. European Urban and Regional Studies, 21(4), 384-397. doi:10.1177/0969776413493631

OECD. (2001a). Citizens as partners: Information, consultation and public participation in policymaking: OECD Publications Service.

OECD. (2001b). Citizens as partners: Information, consultation and public participation in policymaking: Governance. Paris: OECD Publications Service.

Perron, C. (2014). Using partnership to ameliorate regional policies? The case of Mecklenburg-Western Pomerania. European Urban and Regional Studies, 21(4), 398-415. doi:10.1177/0969776413508765

Pestoff, V. (2014). Collective action and the sustainability of co-production. Public Management Review, 16(3), 383-401. doi:10.1080/14719037.2013.841460

Petrova, T., \& Tarrow, S. (2007). Transactional and participatory activism in the emerging European polity: The puzzle of East-Central Europe. Comparative Political Studies, 40(1), 74-94. doi:10.1177/0010414006291189

Piattoni, S. (2009). Multi-level governance: A historical and conceptual analysis. Journal of European Integration, 31(2), 163-180. doi:10.1080/07036330802642755

Polverari, L., \& Michie, R. (2009). New partnership dynamics in a changing cohesion policy context. IQ-Net Thematic Paper. Retrieved from http://www.eprc.strath.ac.uk/iqnet/downloads/IQ-Net_ Reports\%28Public\%29/ThematicPaper25\%282\%29Final.pdf

Pospíšilová, T. (2014). Umbrella organizations in the non-profit sector in the Czech Republic: situation, issues and proposals for action. Retrieved from http://www.vlada.cz/assets/ppov/ rnno/dokumenty/studie_pospisilova_pro_web.pdf

Potluka, O., \& Liddle, J. (2014). Managing European Union Structural Funds: Using a multilevel governance framework to examine the application of the partnership principle at the project level. Regional Studies, 48(8), 1434-1447. doi:10.1080/00343404.2014.898837

Potluka, O., \& Perez, M. (2019). Do candidates from non-profit organisations who adopt party political values improve their chances of electoral success? Policy \& Politics, 47(1), 57-76. doi:https://doi.org/10.1332/030557318X15296528666750

Potluka, O., Špaček, M., \& Remr, J. (2017). NGOs as partners: Obstacles in the EU Cohesion Policy? Ekonomický časopis, 65(8), 715-736. 
Potluka, O., Spacek, M., \& von Schnurbein, G. (2017). Impact of the EU Structural Funds on financial capacities of non-profit organizations. VOLUNTAS: International Journal of Voluntary and Nonprofit Organizations, 28(5), 2200-2223. doi:10.1007/s11266-017-9845-1

Potuček, M. (1999). Havel versus Klaus: Public policy making in the Czech Republic. Journal of Comparative Policy Analysis: Research and Practice, 1(2), 163-176. doi: $10.1080 / 13876989908412622$

Potůček, M. (1999). Havel versus Klaus: Public Policy Making in the Czech Republic. Journal of Comparative Policy Analysis, 1(2), 163-176. doi:10.1023/a:1010023002265

Quigley, K. F. F. (1996). For democracy's sake: How funders fail-and succeed. World Policy Journal, 13(1), 109-118.

Regulska, J. (1999). NGOs and their vulnerabilities during the time of transition: The case of Poland. VOLUNTAS: International Journal of Voluntary and Nonprofit Organizations, 10(1), 61-71.

Rose-Ackerman, S. (2007). From elections to democracy in Central Europe: Public participation and the role of civil society. East European Politics \& Societies, 21(1), 31-47. doi:10.1177/0888325406297132

Salamon, L., M., \& Anheier, H., K. (1998). Social origins of civil society: Explaining the nonprofit sector cross-nationally. VOLUNTAS: International Journal of Voluntary and Nonprofit Organizations, 9(3), 213 - 248. doi:10.1023/A:1022058200985

Salamon, L., M., Sokolowski, S. W., \& Haddock, M., A. (2017). Explaining civil society development: A social origins approach. Baltimore: Johns Hopkins University Press.

Šebík, K. (2016). Selected aspects of candidates standing in local elections in the Slovak Republic. Contemporary European Studies, 1, 5-26.

Sissenich, B. (2010). Weak states, weak societies: Europe's east-west gap. Acta Politica, 45(1-2), 11-40. doi:10.1057/ap.2009.28

Strøm, K., \& Müller, W. C. (2009). Parliamentary democracy, agency problems and party politics. In D. Giannetti \& K. Benoit (Eds.), Intra-Party Politics and Coalition Governments (pp. 25-50). New York: Routledge/ECPR Studies in European Political Science.

Sudbery, I. (2010). The European Union as political resource: NGOs as change agents? Acta Politica, 45(1-2), 136-157. doi:10.1057/ap.2009.27

TNS Opinion \& Social. (2012). Standard Eurobarometer 77: European citizenship. Retrieved from Brussels: http://ec.europa.eu/public_opinion/index_en.htm

TNS Political \& Social. (2013). Flash Eurobarometer 373: Europeans' engagement in participatory democracy. Retrieved from Brussels: http://www.eesc.europa.eu/resources/docs/fl373--report-final-en.pdf 